\title{
MATHEMATICS AND ISLAMIC THOUGHT: SEEING RELATIONSHIP BETWEEN MATHEMATICS AND ISLAMIC TEACHING RESOURCES
}

\author{
Eliva Sukma Cipta \\ Program Studi Pendidikan Guru Madrasah Ibtidaiyah (PGMI) \\ Fakultas Agama Islam Universitas Islam Nusantara Bandung Indonesia \\ elivasukmacipta@uninus.ac.id \\ Muhammad Hori \\ Program Studi Pendidikan Agama Islam (PAl) \\ Fakultas Agama Islam Universitas Islam Nusantara Bandung Indonesia \\ muhammadhori@uninus.ac.id
}

\begin{abstract}
This article tries to discuss about mathematics and islamic thought. By seeing the relationship between mathematics and islamic teaching resources, this article found that science in this world can be classified into three groups, namely natural sciences, social science, and humanities. The natural sciences which consist purely consist of physics, chemistry, and biology, and some people enter mathematics again. The social sciences that fall into the category of pure sciences include sociology, anthropology, psychology, and history. Whereas the humanities consist of philosophy, language and literature, and art. Qur'an and Hadith in the development of science are positioned as sources of qawliyyah verses while the results of observations, experiments, and logical reasoning are positioned as sources of kauniyyah verses. With its position like this, then various branches of knowledge can always be sought from the source of the Qur'an and Hadith. Like, the science of mathematics developed on the basis of the Qur'an and Hadith sources as well as the results of observation, experimentation, and logical reasoning. Mathematics itself has a very close relationship with the spiritual traditions of Muslims, is familiar with the Qur'an, and of course mathematics can also be used as a "path" towards achieving happiness benefits both in this world and the hereafter.
\end{abstract}

Keywords: Mathematics; Islamic thought; genealogical relationship

\section{A. INTRODUCTION}

Knowledge is something that is known by humans through experience (Shook, 2000, p. 132), information (Zhang, 1999, p. 431), feelings or intuition (Waltz, 2003, p. 63). Science is the result of processing reason (thinking) and feeling about something that is known (Venkatappaiah, 1990, p. 110). As intelligent beings, humans observe things (Kvadsheim, 1992, p. v). The results of observations are processed so that it becomes science (Stepin, 2006, p. 75). With this knowledge, humans formulates new knowledge by which all of the needs is fulfilled (Nordin, 2017, p. 96).

In Islamic view, various examples of natural events and objects that exist in this world, can not be thought and processed by humans for the benefit of their lives and to strengthen their faith, except by knowledgeable people who use their knowledge. Allah says: "And these parables are 
we made for man; and no one understands it except those who have knowledge "(Q.S AlAnkabut: 43).

Nasr, as quoted by Azra (Azra, 2010, p. 9), convincingly believes that science in Islam is based on the idea of a transcendent unity which is the heart of revelation in Islam. The emergence of sciences in Islamic civilization and subsequent developments can be understood without the spirit present in Islamic revelation and this pattern of revelation has shaped the thoughts, actions, and circles of Muslim scientists and civilizations responsible for the creation and cultivation of science.

In the 21st century, which is known as the age of technology and information, it has the perception that the Koran only explains about the religious sciences and the history of Islam, whereas in reality the Koran is the source of all things including technology, science, economics and so on. Science in this world can be classified into three groups, namely natural sciences, social science, and humanities. The natural sciences which consist purely consist of physics, chemistry, and biology, and some people enter mathematics again. The social sciences that fall into the category of pure sciences include sociology, anthropology, psychology, and history. Whereas the humanities consist of philosophy, language and literature, and art.

The three types of natural sciences, social sciences, and humanities apply universally, everywhere. It's just that, then among Muslims formulate their own types of science that are sourced from the Qur'an and Sunnah. Some of the aforementioned sciences include sharia, ushuluddin science, tarbiyah science, da'wah science, and manners science, hereinafter referred to as religious science. This kind of trial may require careful and careful review because both religion and general science provide great benefits for life. Especially lately, general science is more likely to contribute to the progress of humanity's science and civilization than religious knowledge that has been constructed by Muslims so far (Azra, 2010, p. 50).

Mathematics is the science of quantity. Mathematics is the science of relationships. Mathematics is the science of forms (abstract). Mathematics is a deductive science. Mathematics is the science of logical structures (Abdusysyakir, 2006, p. 2). The existing definitions are all correct, from a certain point of view. The variety of definitions can be caused by the breadth of the area of study of mathematics itself and the point of view used. But what characterizes mathematics that no other knowledge has is that mathematics is an abstraction from the real world, uses the language of symbols, and adheres to a deductive mindset. To learn mathematics, in addition to knowing the definition of mathematics, it would be better if you first study the characteristics or characteristics of mathematics itself.

The nature or characteristic of mathematics consists of abstract mathematical objects, has symbols that are empty of meaning, relies on agreement, has a deductive mindset, is consistent in its system, and pays attention to the universe of speech (Sumardyono, 2004, p. 31). The existence of this symbol provides a great opportunity for mathematics to be used in various sciences and real life. For example symbols 1,2, 3, 4, and so on do not have any meaning, but the idea of numbers $1,2,3$, and so on exists in the realm of ideas such as the number of objects owned by someone totaling 2 and so on.

Studying natural science is part of studying religion because religion has ordered it. The teachings of Islam commanded his people to study the universe in order to draw closer to Allah for the sake of achieving happiness in the world and the hereafter. Likewise with mathematics, as stated by Abdusysyakir in his book titled Ketika Kyai Mengajar Matematika (When Kyai Teaches Mathematics), mathematics actually has a very close relationship with the spiritual 
traditions of Muslims, is familiar with the Qur'an, and of course mathematics can also be used as a "way "Towards achieving happiness benefits both in this world and the hereafter.

\section{B. METHOD}

Browsing references related to research known as literature studies (DePoy \& Gitlin, 2013, p. 51). This method is used in composing this article. Descriptions are based on the statements of the experts (Ayyub, 2001, p. 243). From the statements of the experts, draw conclusions (McFarland \& Parker, 1990, p. 54)

\section{RESULT AND DISCUSSION}

\section{The Nature of Mathematics}

Etymologically, the word "mathematics" comes from the Greek word "mathema" or maybe also "mathematikos" which means things learned. For the Greeks, mathematics included not only knowledge of numbers and space, but also about music and astronomy. Nasoetion (1980: 12) states that mathematics comes from the Greek "mathein" or "manthenein" which means "to learn". The Dutch, call mathematics with wiskunde, which means exact science. Whereas the Arabs, called mathematics with the knowledge of al reckoning, meaning the science of counting.

In terms of terms, until now there has been no precise definition of mathematics. Philosophers and mathematicians have tried to make mathematical definitions, but until now no one has stated that the answer is the last one. There is no agreed definition to explain what mathematics is. Among the definitions made by mathematicians are as follows: (a) Mathematics is the science of numbers and spaces; (b) Mathematics is the science of quantity (quantity); (c) Mathematics is the science of relationships; (d) Mathematics is the science of form (abstract); (e) Mathematics is a deductive science; and (f) Mathematics is the science of logical structures.

All definitions are correct, based on a certain point of view. The variety of definitions can be caused by the breadth of the area of study of mathematics itself and the point of view used. In terms of the area of study, mathematics starts from a simple scope, which only examines numbers and spaces. Now mathematics has developed by examining things that require a high level of thinking and imagination. From the point of view used, mathematics can be seen from the study space, structure, or other characters.

Although it is difficult to determine the exact definition of mathematics, there are basically characteristics that are easily recognized in mathematics. Characteristics of mathematics that other knowledge lacks are: (a) being an abstraction from the real world; (b) using symbolic language, and (c) adhering to a deductive mindset.

Mathematics is an abstraction from the real world. Abstraction in language means the process of abstracting. Abstraction itself can be interpreted as an effort to create a definition by focusing on the general nature of various objects and ignoring different properties. Because mathematics is an abstraction from the real world, the mathematical object is abstract, but its meaning can be understood.

To state the results of abstraction, we need a communication medium or language. The language used in mathematics is the language of symbols. To express the number "two" the symbol "2" is used. The symbol for numbers is called a number. The use of symbolic language has two advantages, namely (a) simple and universal, and (b) has broad meaning. 


\section{Integration of Mathematics with Islamic Thought}

Sauri in Ahmad Wachidul Kohar quoted by Nihayati meant that integration as a process of combining certain values against another concept so that it became a coherent and inseparable unit or a process of mixing to become a unified whole (Nihayati, 2017). In this context, mathematical material will be combined with the verses of the Koran as the highest source of knowledge in Islamic education so that it becomes a blend of mathematics and religion.

Kuntowijoyo in Fathul Mufid stated that the core of the integration of science is the effort to unite (not merely combine) God's revelation and the discovery of the human mind (rational sciences), not alienating God (secularism) or isolating humans (other wordly asceticism). This integration model is to make the Qur'an and Sunnah a grand theory of knowledge. So that the Kauniyyah and Qawliyyah verses can be used. The integration referred to here is related to efforts to integrate general scholarship with Islam without having to eliminate the uniqueness between the two scholarships. It has been explained before, that the language used in mathematics is the language of symbols. Symbols in mathematics will be meaningful when a context is related to it. Symbols in mathematics are the result of abstraction from the real world. Thus, a symbol actually represents an object both real objects and abstract objects that are ideas. The object represented by a symbol does not always have to be displayed in its concrete form, but can be realized in a concrete form, visualization form, or picture form.

When a symbol language is found without the object being represented, one can understand it according to the object he gave even though the object is different from the actual object represented by the symbol. Determination of the object on a symbol is very dependent on the context or point of view or even the level of imagination of people who read it. The level of imagination will affect the variation of objects associated with symbols and ultimately also affect the visualization of the symbol.

The following clause will be given an example of how to interpret the language of the symbol $x$ = 3 which ultimately can provide a picture and analogy in the treasury of Islamic thought, especially in understanding the Qur'an.

First, when finding the symbol $x=3$, one might not be able to read it. He can see it, but cannot spell it. He did not know the forms written in the symbol. Clearly, this person would not be able to give meaning to the symbol.

Second, when finding the symbol $x=3$, someone might be able to read it, but do not know what exactly the symbol $x=3$ is trying to convey. He knows the forms written in the symbol.

He knows the letter $x$, the sign $=$, and the number 3 , but does not understand what $x$ and 3 what. Obviously, this person would also not be able to give meaning to the symbol.

Third, when finding the symbol $x=3$, one might be able to read it, and begin to associate objects with the forms written on the symbol. He began to understand, in his perspective and imagination, that there was an object equal to 3 . I don't know what objects and 3 are in any unit.

The symbol "=" can be interpreted as price, quantity, or other. At this level, besides being able to make sense, one can generally provide visualization.

Illustration of the meaning of the symbol $x=3$ mathematically geometrically will be analogous to the interpretation of QS Al-Fajr verse 3. Note the following QS Al-Fajr verses 1-3.

Meaning: For the sake of dawn, And for the ten nights. And for the sake of the even and the odd. 
What's with night of ten? What's with even and odd numbers? Why did God swear by the even and odd? Let us see how the existing interpretation of QS AI-Fajr verse 3.

In Jalalain's interpretation, the word "shaf'" is only interpreted as "in pairs" and the word "watr" is interpreted as "alone" without a more detailed explanation. In the interpretation of Ibn Kathir and the interpretation of the Al-Qurthubi there are many interpretations of the word

"Shaf"' and the word "watr" include: (a) as arafah day (9th day) and lahar day (10th day) of the month of Dhul Hijjah; (b) as the midday prayer (2 rak'ahs) and maghrib prayer (3 rak'ahs), or even the whole fard prayer. There are those who are 'even and' who are odd; and (c) as the oath of Allah Almighty for beings and Himself. Syafi is a being and that witr is Allah SWT. Allah is witr, odd, ie wahid (one) while beings are syaf'i or in pairs. There is heaven and earth, there is land and sea, west and east, good and bad, bitter and sweet, tall and short, and so on. All the creations of Allah SWT are in pairs as mentioned in QS Al-Dzariyat verse 49. And we created everything in pairs so that you remember the greatness of God.

Now we will see how likely someone will interpret and understand the verse mathematically geometrically: first, someone cannot read it. Obviously this person can't understand it; second, someone can read it, but do not understand the meaning of words in the language. This person also can't understand it; and third, one can read it and understand the meaning of words in that language.

This person starts associating the words syafi and watr with certain objects. As in existing interpretations, it may be associated with real objects such as numbers, dates, and the number of characters, or even other abstract objects. At a certain level of imagination, one will find the visualization of QS AI-Fajr verse 3 as follows.

Figure-1

The Visualization of Al-Fajr verse 3

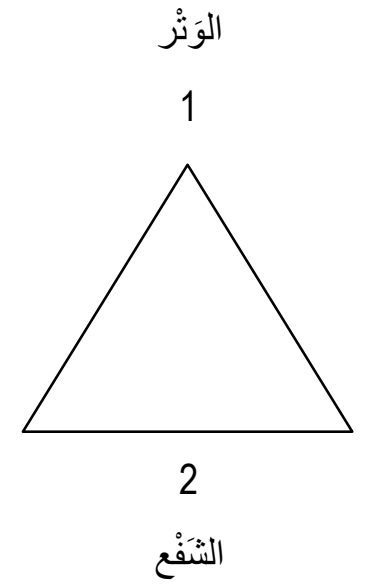

Source: search results, processed

The visualization is made in the form of an equilateral triangle with the number 1 on the top of the triangle and the bottom number 2 . This visualization then requires understanding. These equilateral triangles can be seen as arrows pointing up. As if the arrow said, from the bottom up, from 2 to 1, not from 1 to 2. This interpretation is in accordance with QS Al-Fajr verse 3 which mentions even first, then the odd one. Why is it even first then it's weird? If later even interpreted "creature" created "in pairs" and odd interpreted "khaliq" which is "single / odd", then obtained the meaning that to go to the odd, the one, the first, namely Allah SWT then start by knowing the 
even, in pairs, i.e. creatures (the universe and its contents). This interpretation is in accordance with QS Adz-Dzariyat verse 49 which states that everything in pairs is a means to remember the power of Allah SWT.

Even in a hadith it is stated that "think about the creation of Allah SWT, don't think about the essence of Allah SWT". That is, that to get to know Allah SWT the means is by knowing and studying His creation, namely by knowing and studying the universe. Then why are the equilateral triangles, not the others? First, we need to remember Muhammad's prophetic seal containing the shape of an equilateral triangle. Second, equilateral triangles show balance in size. All the creations of Allah SWT are balanced, orderly, and neatly arranged. Note the QS AIMulk verse 3.

Meaning: Who created the seven heavens in layers. You never look at the creation of God, the Most Gracious, of something out of balance. Then look again and again, do you see anything that is out of balance?

Thus one interpretation of the Qur'an uses a geometrical mathematical approach, which does not contradict the existing interpretations both in the interpretations of Jalalain, Ibn Kathir, and the Al-Qurthubi. Even this mathematical approach provides a deeper explanation.

\section{CONCLUSSION}

There is no creation of Allah SWT in vain, including mathematics. Even mathematics is the language used in the creation of the universe. Thus, to learn and understand the verses of Kauniyah (the universe), mathematics is needed. An understanding of the universe will lead to the wonder of the power of Allah SWT. In addition, mathematics is also able to provide a deeper approach to understanding the verses of Qawliyah (the Qur'an).

Science is the result of processing reason (thinking) and feeling about something that is known. Various examples of natural events and objects that exist in this world, can not be thought and processed by humans for the benefit of their lives and to strengthen their faith, except by knowledgeable people who use their knowledge. In the 21st century, which is known as the age of technology and information, it has the perception that the Koran only explains about the religious sciences and the history of Islam, whereas in reality the Koran is the source of all things including technology, science, economics and so on.

The Koran was revealed to humans as a differentiator between rights and vanity, also led humans to demand and develop knowledge. Knowledge about Islam that originates in the Koran and Hadith should not be positioned in a separate place separate from other knowledge groups, but should be placed as a source of knowledge. Alquran and hadith in the development of science are positioned as sources of qawliyyah verses while the results of observations, experiments, and logical reasoning are positioned as sources of kauniyyah verses. With its position like this, then various branches of knowledge can always be sought from the source of the Qur'an and hadith. Like, the science of mathematics developed on the basis of the Qur'an and hadith sources as well as the results of observation, experimentation, and logical reasoning. Mathematics itself has a very close relationship with the spiritual traditions of Muslims, is familiar with the Qur'an, and of course mathematics can also be used as a "path" towards achieving happiness benefits both in this world and the hereafter. 


\section{REFERENCES}

Abdusysyakir. (2006). Ada Matematika dalam al Qur'an. Malang: UIN-Malang Press.

Ayyub, B. M. (2001). Elicitation of Expert Opinions for Uncertainty and Risks. Boca Raton: CRC Press.

Azra, A. (2010). Strategi Pendidikan: Upaya Memahami Wahyu dan Ilmu. Yogyakarta: Pustaka Pelajar.

DePoy, E., \& Gitlin, L. N. (2013). Introduction to Research - E-Book: Understanding and Applying Multiple Strategies. Missouri: Elsevier Health Sciences.

Kvadsheim, R. (1992). The Intelligent Imitator: Towards an Exemplar Theory of Behavioral Choice. Amsterdam: Elsevier.

McFarland, T. D., \& Parker, R. (1990). Expert Systems in Education and Training. New Jersey: Educational Technology.

Nihayati, N. (2017). INTEGRASI NILAI-NILAI ISLAM DENGAN MATERI HIMPUNAN (KAJIAN TERHADAP AYAT-AYAT AL-QUR'AN). JURNAL E-DuMath, 3(1), 65-77. https://doi.org/10.26638/je.285.2064

Nordin, I. (2017). Using Knowledge: On the Rationality of Science, Technology, and Medicine. Lanham: Lexington Books.

Shook, J. R. (2000). Dewey's Empirical Theory of Knowledge and Reality. Nashville: Vanderbilt University Press.

Stepin, V. S. (2006). Theoretical Knowledge. Dordrecht: Springer Science \& Business Media.

Sumardyono. (2004). Karakteristik Matematika dan Implikasinya terhadap Pembelajaran Matematika. Yogyakarta: Departemen Pendidikan Nasional: Direktorat Jenderal Pendidikan Dasar dan Menengah Pusat Pengembangan Penataran Guru Matematika.

Venkatappaiah, V. (1990). Dimensions of Library and Information Science: Kaula Festschrift : Papers Contributed in Honour of Prof. P.N. Kaula on His Sixty-first Birthday. New Delhi: Concept Publishing Company.

Waltz, E. (2003). Knowledge Management in the Intelligence Enterprise. Boston London: Artech House.

Zhang, Y.-Q. (1999). Visual Information Representation, Communication, and Image Processing. New York - Basel: CRC Press. 